\title{
Choroidal and Ciliary Body Melanoma Pathologic Primary Tumor TNM Finding v8
}

National Cancer Institute

\section{Source}

National Cancer Institute. Choroidal and Ciliary Body Melanoma Pathologic Primary

Tumor TNM Finding v8. NCI Thesaurus. Code C140630.

A pathologic finding about one or more characteristics of choroidal and ciliary body melanoma, following the rules of the TNM AJCC v8 classification system as they pertain to staging of the primary tumor. 